\title{
АТОМИСТИЧЕСКИЙ ПОДХОД В МЕТОДОЛОГИИ Н.И. ВАВИЛОВА: ЗАКОН ГОМОЛОГИЧЕСКИХ РЯДОВ ГЛАЗАМИ КРИСТАЛЛОГРАФА М.Е. Раменская
}

Географический факультет Московского государственного университета им. М.В. Ломоносова,

Москва, Россия

Эл.nочта: ramusa@yandex.ru

Статья поступила в редакиию 23.06.2014; принята к печати 16.10.2014

В генетических исследованиях Н.И. Вавилов использовал атомистическую методологию, разработанную химией в основном в ХІХ в. Это он неоднократно подчеркивал, сравнивая генетику с химией. Главные свои открытия - закон гомологических рядов в наследственной изменчивости и определение центров происходения культурных растений - он сделал, опираясь на эту методологию.

Ключевые слова: Н.И. Вавилов, гомологчческие ряды, гены, признаки, атомы, молекуль, системы и классы кристаллографической симметрии.

THE ATOMISTIC APPROACH IN N.I. VAVILOV'S METHODOLOGY:

THE LAW OF HOMOLOGOUS SERIES IN THE EYES OF CRYSTALLOGRAPHER M.Ye. Ramenskaya

Geographical Department, M.V. Lomonosov University, Moscow, Russia

E-mail:ramusa@yandex.ru

N.I. Vavilov used the atomistic methodology, which was worked out in the 19th century by chemists, in his genetic investigations. He highlighted this many times by comparing genetics and chemistry. His most important discoveries, including the Low of homologous series and the identification of the centers of origin of cultivated plants, are based on atomistics.

Keywords: N.I. Vavilov, homological series, genes, traits, atoms, molecules, systems and classes of crystallographical symmetry.

\section{Введение}

4 июня 1920 г. на III Всероссийском съезде по селекции и семеноводству один из организаторов съезда, мало кому известный тогда выпускник Московского сельскохозяйственного института Николай Иванович Вавилов прочитал доклад «Закон гомологических рядов в наследственной изменчивости» [4, c. 10-22]. Закон позволял систематизировать необозримое разнообразие культурных растений и предвидеть их биологические и агрономические свойства на основании знаний о родственных видах и родах. В чем суть этого закона?

Генетика родилась, когда стало ясно, что каждый из тысяч признаков, которыми обладают растение или животное, передается потомству независимо от остальных (в этом состоит открытие Менделя). Было установлено, что у потомков одной родительской пары каждый из признаков представлен двумя альтернативными вариантами (аллелями). Изучение культурных растений показало, что в пределах вида таких вариантов больше двух, иногда - десятки. Открытый Н.И. Вавиловым закон гласил, что эти ряды признаков у близких видов повторяются. По аналогии с термином органической химии Н.И. Вавилов свой закон повторения признаков у соседних таксонов назвал законом гомологических (параллельных, сходных по строению) рядов в наследственной изменчивости.
Закончил Н.И. Вавилов свой доклад словами:

«Может быть, более правильно проводить аналогию гомологических рядов растений и животных не только с рядами органической химии, но и с системами и классами кристаллов.

$<\ldots>$ В заключение позволим только выразить твердое убеждение, что наиболее целесообразным и обещающим путем изучение многообразия мира растений и животных, открывающегося перед селекционером в ближайшем будущем, нам представляется путь установления параллелизмов и гомологических рядов изменчивости» [4, с. 22].

Что же имел в виду Н.И. Вавилов, сравнивая признаки живых организмов с системами и классами кристаллов, и какое еще можно найти сходство между законами генетики и кристаллографии?

\section{Параллельность рядов из сходных элементов в биологических объектах и в законах кристаллографической симметрии}

Классы симметрии кристаллов, относящиеся к разным системам, - это уже не структуры, а закономерности. Но и они образуют параллельные ряды, что можно видеть из рис. 1 [7].

Симметрия - это некоторая инвариантность. Перемещая или изменяя тело по какому-либо закону, мы совмещаем его с самим собой, получаем положение, 


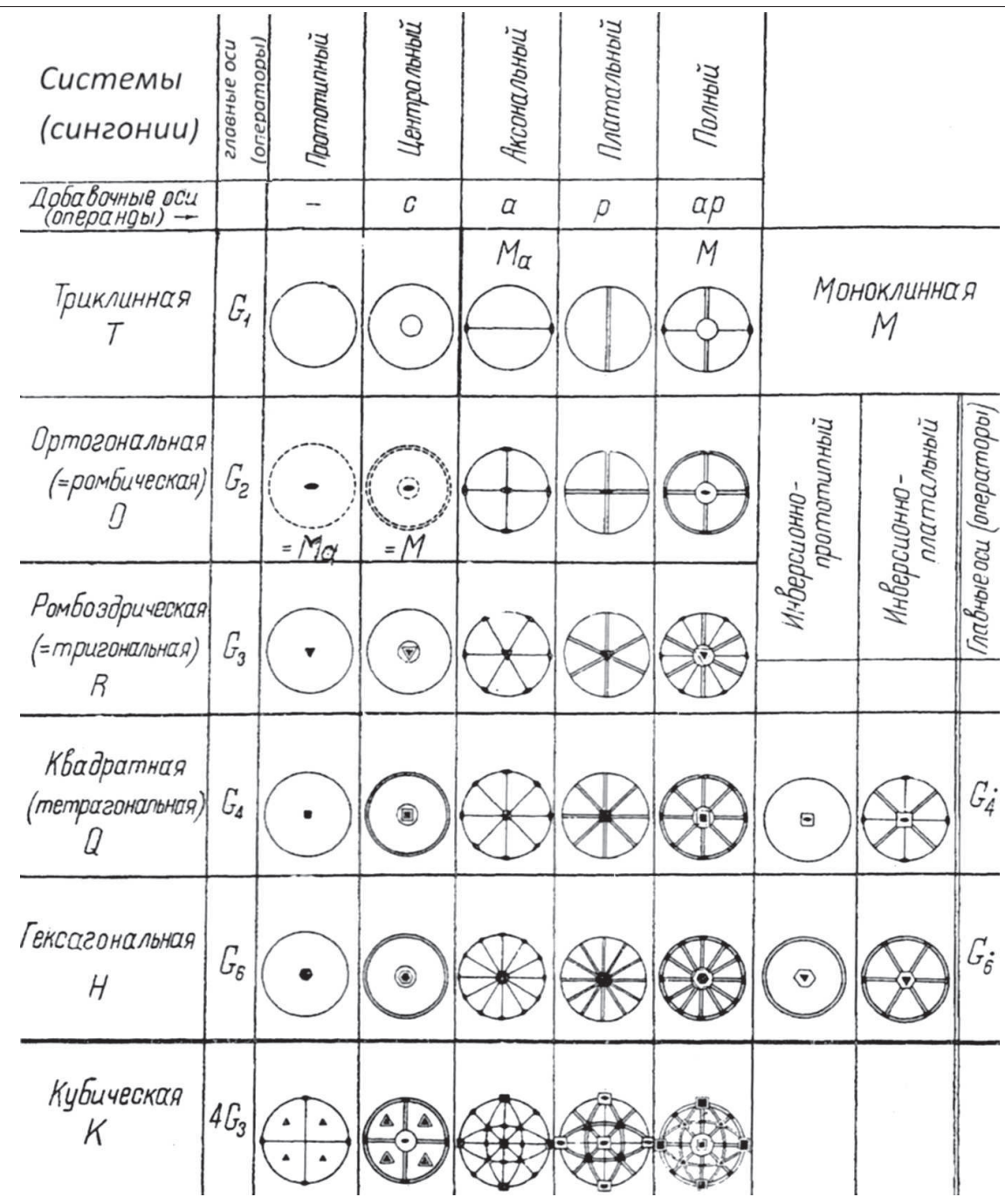

Pис. 1. Классы симметрии кристаллов (по [7]). Объяснения в тексте

равное исходному. Каждая кристаллографическая система характеризуется главной осью. В системах кристаллов существуют оси первого (симметрия отсутствует, тело совмещается с собой при повороте на $360^{\circ}$ один раз (обозначается $\mathrm{G}_{1}$ ); второго, третьего, четвертого и шестого порядков (соответственно, $\mathrm{G}_{2}$, $\mathrm{G}_{3}, \mathrm{G}_{4}$ и $\mathrm{G}_{6}$ : тело при повороте на $360^{\circ}$ совмещается с собой дважды, трижды, четырежды или 6 раз). На рис. 1 на проекции каждого класса симметрии главная ось расположена перпендикулярно плоскости проекции и показана в виде линзы (второй порядок) либо правильного многоугольника, соответствующего порядку оси. На рисунке к главной оси добавлены различные элементы симметрии: параллельная оси, то есть вертикальная, зеркальная плоскость (двойная линия), перпендикулярная оси горизонтальная плоскость (двойная окружность), перпендикулярная главной оси ось второго порядка (линия с линзами на концах) и другие. В соответствии с геометрическими законами, появляются новые элементы симметрии и повторяются прежние. На рис. 1 сохранены 2 случая повторяющихся сочетаний, они обозначены М и М. $\mathrm{B}$ строке $\mathrm{G}_{1}$ ось $\mathrm{G}_{2}$ расположена горизонтально и является дополнительной, перпендикулярной оси $\mathrm{G}_{1}$, в строке $\mathrm{G}_{2}$ она как порождающая (оператор) расположена вертикально. Таким образом, сочетания повернуты на $90^{\circ}$, но одинаковы. Если из повторяющихся сочетаний элементов оставить по одному, получаем
32 сочетания элементов симметрии - законы симметрии, по которым формируются кристаллы, они и называются классами кристаллографической симметрии. Системами называют совокупности классов, объединенные наличием общей главной оси. Математически строго доказано существование 32 классов, и на рисунке все они показаны (как уже отмечено, два из них - дважды), причем видно, что в соседних системах симметрии кристаллов классы находят себе аналоги: ряды классов симметрии соседних систем параллельны. Лишь в тетрагональной и гексагональной системах есть по 2 лишних класса, так что эти 2 параллельных ряда полнее остальных.

Е.С. Федоров на базе 32 классов симметрии открыл 230 групп симметрии для бесконечных структур. В каждом классе имеется несколько групп, образующих параллельные ряды с подобными группами соседних классов. Чем ближе группы, тем более сходны и ряды. Любая кристаллическая структура относится по расположению атомов к одной из этих групп.

Все макроскопические кристаллы (на наноуровне действуют несколько иные законы) подчиняются требованиям этих классов симметрии: атомы расположены по одному из 230 законов Федоровских групп. Все нарушения симметрии, связанные с воздействиями внешней среды, все особенности реальных кристаллографических форм изучают на осно- 
вании этих законов. И, учитывая их, мы наверняка знаем, что никакой новый кристалл не вырастет, проявив иную симметрию, скажем, в виде пятиконечной звезды или правильной семигранной призмы.

Почему Н.И. Вавилов обратил внимание на параллельность законов симметрии? Возможно, он хотел подчеркнуть, что за параллельностью наследственной изменчивости скрывается параллельность каких-то неизвестных науке глубинных законов.

Во всяком случае, открытые Н.И. Вавиловым в биологии гомологические ряды так же, как законы кристаллографической симметрии, позволяют предсказать, что может быть обнаружено, а что - нет. Так, Н.И. Вавилов предупреждал: вряд ли возможно получить с помощью селекции синюю розу, так как среди розоцветных ни у одного вида нет синих цветов.

Н.И. Вавилов в последних словах своего доклада подчеркнул, что суть открытого им закона - в параллельности неких структур и связанных с ними свойств. То есть, если мы нашли определенный признак у особей одного из видов данного рода, найдем в природе, либо сможем получить с помощью мутагенеза этот признак и у представителей других видов этого рода и даже семейства. Почему получим с помощью мутагенеза? Потому что признаки, морфологические, физиологические, биохимические и другие, о которых идет речь в законе Н.И. Вавилова, являющиеся внешними (фенотипическими) проявлениями различных генов, - это результаты элементарных актов «неопределенной изменчивости» Дарвина. Или, что то же самое, - результаты мутаций Де-Фриза.

Слушатели доклада с энтузиазмом встретили открытие, которое могло быть полезным для селекционеров [4, с. 247]. Однако генетики отнеслись к нему гораздо холоднее.

Открытие было сделано на тысячах образцов культурных растений, относящихся к десяткам биологических родов и видов на основе того же гибридологического анализа, с помощью которого в свое время Г. Менделем была установлена дискретность наследственных признаков. Но к 1920 г. генетики с помощью изучения потомков одной родительской пары проникли в тонкое строение генов, и гибридологический анализ был для них слишком примитивен и груб. Выводы, сделанные Н.И. Вавиловым на массовом материале, казались им недостаточно обоснованными. К тому же они понимали, что не всегда одни и те же признаки обеспечиваются одними и теми же генами, и требовали, чтобы в каждом случае это было строго доказано. Н.И. Вавилов это понимал тоже. Уже в английском варианте статьи «Закон гомологических рядов в наследственной изменчивости», опубликованном в 1922 г., он подчеркнул, что помимо гомологических рядов сходных признаков, обусловленных существованием родственных, сходных по структуре, генов, существуют ряды аналогические, когда сходство признаков случайно и обеспечивается независимыми факторами [4, с. 48].

Интересно, что во второй половине прошлого века при разработке общей теории систем было установлено, что у системных объектов самой различной природы могут быть обнаружены сходства уже на том основании, что объекты - системные. А существует еще и сходство, основанное на общей структуре, в свою очередь, обусловленной родством [19]. Таким образом, уже в работе Н.И. Вавилова от 1922 г. указано на существование обоих случаев сходства, описанных позже общей теорией систем.

\section{Атомистическая методология, разработанная химией, и ее место в биологии}

Н.И. Вавилов вступил в научную жизнь в годы торжества атомистических воззрений. В 1900 г. было понято, что явление радиоактивности представляет собой распад атома. Это стало полной победой атомистики - последним доказательством того, что атом - реальное тело, а не удобная для рассуждений и расчетов абстракция. Вскоре возникло понятие кванта, «атома» энергии, и в том же году одновременно три исследователя вторично открыли не понятые до победы атомистики законы Менделя. Стало ясно, что наследственные задатки так же дискретны, как и вещество.

Именно так воспринял законы Менделя Н.И. Вавилов. Уже первую свою лекцию, прочитанную 2 октября 1912 г., он посвятил теме «Генетика и ее отношение к агрономии». Рассказав об опытах Менделя, лектор заключил: «Теоретический вывод громадной важности, сделанный Менделем из его опытов, был тот, что для того, чтобы разобраться в явлениях наследственности, надо рассматривать организм как составленный из отдельных признаков, самостоятельно и независимо ведущих себя при скрещивании $<\ldots>$, которые могут по определенным правилам замещаться соответствующими признаками других близких растений с помощью скрещивания. Проведя несколько утрированную аналогию, французский биолог Бларингем приравнивает открытие Менделя установлению им состава организмов и законов, управляющих заменой одних компонентов другими» [4, с. 103].

Это сравнение генетики с химией служило Н.И. Вавилову в течение всей его научной деятельности; он положил его в основу своей методологии.

Атомистическую методологию генетикам на пустом месте создавать не пришлось: она была разработана химиками в течение XIX в. Философы, исследовавшие в середине XX в. особенности атомистической методологии, - Б.М. Кедров и В.А. Чудинов, - называют 4 этапа развития атомистики: 1) установление дискретности; 2) выявление порядка расположения дискретных элементов в природных телах; 3) классификация их и, наконец, как вершина, 4) разрушение дискретных элементов и выявление их структуры. Далее изучаются дискретные частицы, из которых состоял дискретный элемент (то есть, в случае химии, - атом). Таким образом, повторяется то же самое на новом структурном уровне организации $[11,22]$. О том, что необходимо изучать эти дискретные элементы в природе сами по себе, выявлять их распределение в пространстве и времени, - философы забыли.

Законы простых кратных отношений Гаюи и Дальтона позволяют думать, что предполагавшиеся еще в античности атомы или неделимые элементы мира представляют собой атомы химических элементов. Это - первый этап проявления атомистической методологии в химии. В генетике этому этапу соответствует открытие (до победы атомистики не понятое), а затем переоткрытие законов Менделя. С помощью 
гибридизации и изучения потомства (гибридологический) Г. Мендель установил дискретность и независимость передачи потомству признаков у организмов. Всеобщность открытых Менделем законов доказал учитель Н.И. Вавилова В. Бетсон, повторив его исследования на ряде млекопитающих, насекомых и растений.

Второй этап разработки атомистической методологии в химии - построение структурных формул (Ф.А. Кекуле, А.М. Бутлеров, Я.Х. Вант Гофф) - в XIX в. привел к представлению о единой структуре всех веществ: атом-молекула-физическое тело. Правда, позже оказалось, что это относится далеко не ко всем веществам.

По наличию тех или иных элементов структуры были выделены гомологические ряды молекул. Пример одного из гомологических рядов - это полициклические ароматические углеводороды (ПАУ), широко распространенные в природе (рис. 2). Их объединяет основа их структуры - конденсированные бензольные кольца. Внутри бензольных колец действуют самые сильные из химических связей - ковалентные. Электроны внутри всех колец молекулы свободно передвигаются, а по ее краям, к вершинам внешних шестиугольников, присоединены одновалентные атомы водорода. На рисунке атомы водорода в соответствии с традицией не показаны. Между каждой молекулой и остальным миром действуют самые слабые связи, уже не химические, а физические: Ван-дер-ваальсовые. Среди общих свойств ПАУ, обеспеченных этой структурой, - плохая растворимость в воде, несколько лучшая в рассолах и хорошая в углеводородах; способность люминесцировать, а в быстро замороженных сильно разбавленных растворах давать структурные спектры люминесценции. По этим спектрам в самой сложной смеси можно определять индивидуальные ПАУ. Помимо них, примерами гомологических рядов можно считать ряды из предельных цепочечных углеводородов с общей формулой $\mathrm{C}_{\mathrm{n}} \mathrm{H}_{2 \mathrm{n}+2}$, (пример, приведенный Н.И. Вавиловым $[4$, c. 52]); ряды из получаемых на их основе спиртов $\mathrm{C}_{\mathrm{n}} \mathrm{H}_{2 \mathrm{n}+1} \mathrm{OH}$, органических кислот с общей группой $-\stackrel{n}{\mathrm{C}}=\stackrel{2 n}{\mathrm{O}} \mathrm{OH}$ и другие. Все соединения каждого гомологического ряда имеют не только общую структуру, но и основанные на ней общие свойства.
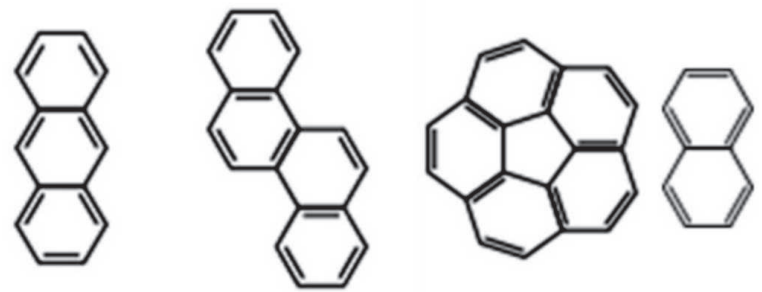<smiles>c1ccc2c(c1)c1ccccc1c1ccccc21</smiles>

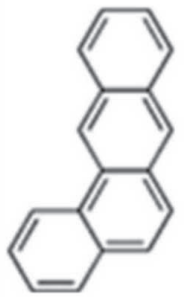

Рис. 2. Примеры структуры полициклических ароматических соединений

В 1914 г., когда были опубликованы результаты расшифровки первых кристаллических структур, стало ясно, что неорганические соединения состоят вовсе не из молекул [1]. Между тем, в средней школе до сих пор не учат, что из молекул состоят практически лишь некоторые органические вещества, газы атмосферы да свободная сера. Большинство же неорганических тел либо построены непосредственно из атомов или их ионов (рис. 3), либо являются гетеродесмичными, то есть атомы соединены в них связями разного характера и разной силы (рис. 4).

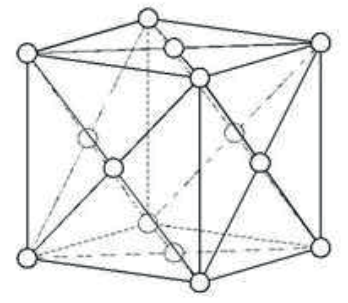

A

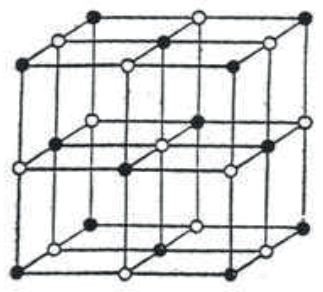

B

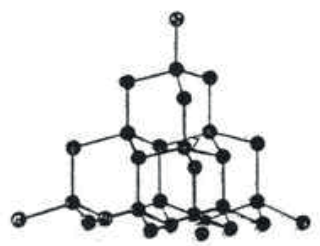

B

Рис. 3. Примеры структуры неорганических веществ: А - медь; Б - поваренная соль; В - алмаз

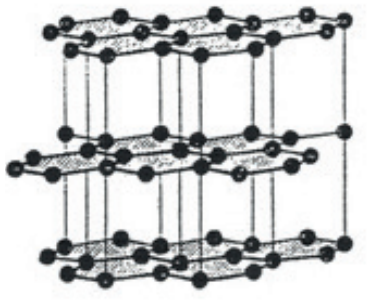

A

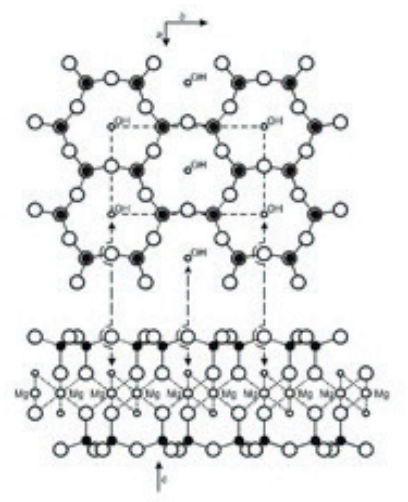

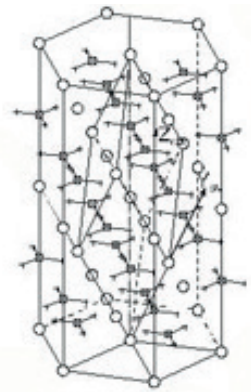

Б

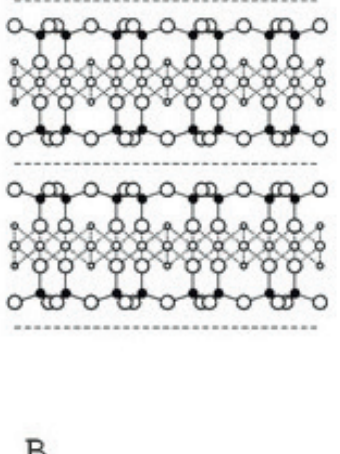

B

Рис. 4. Примеры гетеродесмичных соединений: А - графит; Б - кальцит; В - тальк 
Примерами соединений, состоящих из отдельных атомов, могут служить кристаллы металлов, хлористого натрия или алмаза. Кристаллы металлов, например меди (рис. 3А), состоят из атомов (ядро и внутренние электронные оболочки) и электронов внешних оболочек. Эти внешние электроны, с одной стороны, стягивают атомы в простирающиеся бесконечно в трех измерениях структуры, а с другой, свободно перемещаются внутри всего кристалла, что и обеспечивает электропроводность металлов. Такая связь называется металлической. Кристаллы поваренной соли (рис. ЗБ) состоят из положительно заряженных металлических атомов (катионов) натрия и отрицательно заряженных неметаллических атомов (анионов) хлора. Их связывают в бесконечный кристалл электростатические силы - это ионная химическая связь. Алмаз (рис. 3В) является как бы бесконечной молекулой: он состоит только из атомов углерода, каждый из которых связан с четырьмя другими такими же атомами ковалентной связью.

Примерами гетеродесмичных соединений могут служить весьма непохожие по строению и свойствам графит, кальцит и силикаты. Графит (рис. 4А) представляет собой бесконечные сетки из конденсированных, как в ПАУ, бензольных колец. Внутри сеток действуют ковалентные связи, это как бы бесконечные молекулы ПАУ (графен). Между сетками, наложенными в кристалле друг на друга, действуют Ван-дер-Ваальсовы силы. В кальците (рис. 4Б) электростатическими силами в бесконечную структуру связаны ионы металла и группы $\mathrm{CO}_{3}^{2-}$; внутри последних - между атомами углерода и кислорода - действуют связи, близкие к ковалентным, переходные от них к ионным - донорно-акцепторные. У силикатов анионы представляют собой кремнекислородные тетраэдры, либо одиночные, либо связанные между собой в бесконечные структуры кольца, цепи, пластины, каркасы - с помощью общих для соседних тетраэдров атомов кислорода. Внутри тетраэдров, между атомами кремния и кислорода, действуют донорно-акцепторные связи. Катионы же, как у кальцита, представлены одиночными ионами, но не только кальция, а самых разных металлов, которые связывают кремнекислородные анионы между собой. Например, в структуре талька кремнекислородные пластины и анионы ОН связывают в пачки электростатическими (ионными) силами катионы $\mathrm{Mg}^{2+}$, а между пачками действуют силы Ван-дер-Ваальса (рис. 4В). В других силикатах кремнекислородные тетраэдры образуют параллельные цепочки или даже трехмерные каркасы.

Как мы видим, твердые тела состоят из отдельных атомов, групп атомов, бесконечных образований из атомов и даже, в случае металлической связи, из атомов и электронов. А электроны - это уже элементарные частицы, то есть элементы системного объекта атом. Таким образом, химия и кристаллография установили, что вещество состоит не исключительно из атомов, связанных в молекулы, а из частей, относящихся к разным уровням организации. Но атомистических воззрений это нисколько не поколебало, лишь указало на сложность атомной структуры веществ ${ }^{1}$.

Был ли Н.И. Вавилов знаком с этими особенностями строения вещества? Место внешних электронов в строении металлов он
Генетика на втором этапе развития атомистической методологии (изучение взаимного положения атомов-генов) представлена в первую очередь работами Т.Г. Моргана. Им разработаны достаточно тонкие методы, с помощью которых доказано линейное расположение генов в хромосоме и открыто множество деталей передачи наследственной информации. Этим методом генетика работает и теперь, изучая геномы отдельных видов, с его помощью она изучила различные уровни организации генов и перешла к новым методам - методам молекулярной генетики. Таким образом, она сразу приступила к четвертому этапу развития атомистической методологии.

В химии для третьего этапа развития атомистики классификации атомов - Д.И. Менделеев использовал данные всего арсенала химии и кристаллографии: свойства простых веществ и их соединений, законы изоморфных замещений и атомный вес каждого элемента. Только такой массив данных позволил ему открыть периодическую систему и предсказать существование еще не известных элементов. И все же существование 5 элементов восьмой группы он предвидеть не мог. Но, как только был обнаружен один, из открытой Менделеевым системы элементов стало ясно, что существуют еще 4.

Участники III Всероссийского съезда селекционеров и семеноводов приравняли открытие Н.И. Вавилова к открытию Д.И. Менделеева в химии [4, с. 249]. Как и Менделеев, Вавилов использовал огромный массив фактов. Но в данном случае это были результаты преимущественно собственных исследований Н.И. Вавилова вместе с работавшим под его руководством коллективом опытных станций при Саратовском университете и Саратовском отделении Бюро прикладной ботаники. Этими фактами были передающиеся по наследству (что было установлено методом гибридологического анализа) признаки тысяч образцов культурных растений, изучавшихся на этих станциях. Именно признаки, а не организмы со всей совокупностью признаков, как это было до сих пор, изучали Н.И. Вавилов и его коллектив. На основе фактов они составляли таблицы. В них столбцы представляли полный набор всех сортов вида (или видов внутри рода), а строки - наборы вариантов каждого признака. Пример такой таблицы (часть многостраничной таблицы, построенной для семейства злаковых) приведен на рис. 5.

знать не мог - оно было открыто после гибели Н.И. Вавилова. Другие особенности строения твердых тел он мог знать от младшего брата, С.И. Вавилова - физика, со студенческих лет занимавшегося взаимодействием света с веществом. Однако люминесценцией твердых тел, исследование которой особенно требует знание кристаллографии, С.И. занялся позже 1922 г. Знаменитый физикохимик, сын русских эмигрантов Моисей Натанович Гайсинский, после Второй мировой войны - директор Института М. Кюри в Париже, - в студенческие годы участвовал в экспедиции Вавилова по Средиземноморью, потом долго переписывался с ним. Вавилов посылал ему литературу по физике и химии. Так вот, первую свою книгу под названием «Атомистика в современной химии», вышедшую в свет в 1930 г. на итальянском языке, Гайсинский послал Н.И. Вавилову [5]. Вполне возможно, что рассмотренные в книге проблемы М.Н. Гайсинский и Н.И. Вавилов обсуждали и до написания этой книги. К сожалению, библиотека Н.И. Вавилова сохранилась не полностью. Ни у сына Н.И., ни в библиотеке Ботанического института, куда попала большая ее часть, этой книги нет. Но знакомство со студентом Гайсинским завязалось лишь в 1926 г. Впрочем, достаточно представлять разнообразие и сложность строения молекул, чтобы предположить еще большую сложность для генов. И, если Н.И. Вавилов о строении кристаллов от Гайсинского узнал, это только подтвердило его представления о сложности генома. 


\begin{tabular}{|c|c|c|c|c|c|c|c|c|c|}
\hline Наследственно варьирующие признаки & $\begin{array}{c}P \\
0 \\
w \\
b\end{array}$ & $\begin{array}{l}\text { П } \\
\text { w } \\
\mathrm{e} \\
\mathrm{H} \\
\mathrm{n} \\
4 \\
\mathrm{a}\end{array}$ & $\begin{array}{l}\text { Я } \\
4 \\
M \\
\text { e } \\
\text { H } \\
\text { b }\end{array}$ & $\begin{array}{l}\text { O } \\
\text { B } \\
\text { ë } \\
c\end{array}$ & $\begin{array}{l}\Pi \\
p \\
o \\
c \\
o\end{array}$ & $\begin{array}{l}c \\
o \\
p \\
r \\
o\end{array}$ & $\begin{array}{l}\mathrm{K} \\
\mathrm{y} \\
\mathrm{K} \\
\mathrm{y} \\
\mathrm{p} \\
\mathrm{y} \\
3 \\
\mathrm{a}\end{array}$ & $\begin{array}{l}\mathrm{P} \\
\mathrm{u} \\
\mathrm{c}\end{array}$ & $\begin{array}{l}\text { П } \\
\text { bl } \\
\text { p } \\
\text { e } \\
\text { й }\end{array}$ \\
\hline $\begin{array}{l}\text { двуцветковые } \\
\text { многоцветковые }\end{array}$ & $\begin{array}{l}+ \\
+ \\
\end{array}$ & $\begin{array}{l}+ \\
+ \\
\end{array}$ & $\begin{array}{l}+ \\
- \\
\end{array}$ & $\begin{array}{l}+ \\
+ \\
\end{array}$ & + & $\begin{array}{l}+ \\
- \\
\end{array}$ & $\begin{array}{l}+ \\
- \\
\end{array}$ & $\begin{array}{l}+ \\
- \\
\end{array}$ & $\begin{array}{l}+ \\
+ \\
\end{array}$ \\
\hline $\begin{array}{l}\text { Окраска колосковых и цветковых чешуй } \\
\text { белая (соломенно-жёлтая) } \\
\text { красная } \\
\text { бурая } \\
\text { серая (чёрная) } \\
\text { фиолетовая (антоциановая) }\end{array}$ & $\begin{array}{l}+ \\
+ \\
+ \\
+ \\
+\end{array}$ & $\begin{array}{l}+ \\
+ \\
+ \\
+ \\
+\end{array}$ & $\begin{array}{l}+ \\
+ \\
+ \\
+ \\
+\end{array}$ & $\begin{array}{l}+ \\
+ \\
+ \\
+ \\
+\end{array}$ & $\begin{array}{l}+ \\
+ \\
+ \\
+ \\
+\end{array}$ & $\begin{array}{l}+ \\
+ \\
+ \\
+ \\
+\end{array}$ & $\begin{array}{l}+ \\
+ \\
+ \\
+ \\
+\end{array}$ & $\begin{array}{l}+ \\
+ \\
+ \\
+ \\
+\end{array}$ & $\begin{array}{l}+ \\
+ \\
+ \\
+ \\
+\end{array}$ \\
\hline $\begin{array}{l}\text { Опушение колосковых и цветковых чешуй } \\
\text { опушённые } \\
\text { голые }\end{array}$ & $\begin{array}{l}+ \\
+ \\
\end{array}$ & $\begin{array}{l}+ \\
+ \\
\end{array}$ & $\begin{array}{l}+ \\
+ \\
\end{array}$ & $\begin{array}{l}+ \\
+ \\
\end{array}$ & $\begin{array}{l}- \\
+ \\
\end{array}$ & $\begin{array}{l}+ \\
+ \\
\end{array}$ & $\begin{array}{l}+ \\
- \\
\end{array}$ & $\begin{array}{l}+ \\
+ \\
\end{array}$ & $\begin{array}{l}+ \\
+ \\
\end{array}$ \\
\hline $\begin{array}{l}\text { Колосовой стержень } \\
\text { простой } \\
\text { ветвистый }\end{array}$ & $\begin{array}{l}+ \\
+ \\
\end{array}$ & $\begin{array}{l}+ \\
+ \\
\end{array}$ & $\begin{array}{l}+ \\
+ \\
\end{array}$ & $\begin{array}{l}- \\
- \\
\end{array}$ & - & - & $\begin{array}{l}+ \\
+ \\
\end{array}$ & $\begin{array}{l}- \\
- \\
\end{array}$ & $\begin{array}{l}+ \\
- \\
\end{array}$ \\
\hline $\begin{array}{l}\text { Опушённость колосового стержня и цветоножек } \\
\text { сильно опушённые } \\
\text { голые } \\
\text { слабо опушённые }\end{array}$ & $\begin{array}{l}+ \\
- \\
+\end{array}$ & $\begin{array}{l}+ \\
+ \\
+\end{array}$ & $\begin{array}{l}+ \\
+ \\
+\end{array}$ & $\begin{array}{l}+ \\
+ \\
+\end{array}$ & $\begin{array}{l}+ \\
+ \\
+\end{array}$ & $\begin{array}{l}+ \\
+ \\
+\end{array}$ & $\begin{array}{l}+ \\
- \\
+\end{array}$ & $\begin{array}{l}+ \\
- \\
+\end{array}$ & $\begin{array}{l}+ \\
+ \\
+\end{array}$ \\
\hline $\begin{array}{l}\text { Восковой налёт на колосковых и цветковых чешуях } \\
\text { есть } \\
\text { нет }\end{array}$ & $\begin{array}{l}+ \\
+ \\
\end{array}$ & $\begin{array}{l}+ \\
+ \\
\end{array}$ & $\begin{array}{l}+ \\
+ \\
\end{array}$ & $\begin{array}{l}+ \\
+ \\
\end{array}$ & $\begin{array}{l}+ \\
+ \\
\end{array}$ & $\begin{array}{l}+ \\
+ \\
\end{array}$ & $\begin{array}{l}+ \\
+ \\
\end{array}$ & $\begin{array}{l}+ \\
+ \\
\end{array}$ & $\begin{array}{l}+ \\
+\end{array}$ \\
\hline $\begin{array}{l}\text { Окраска: } \\
\text { белое } \\
\text { красное } \\
\text { зелёное (серозелёное) } \\
\text { чёрное (тёмносерое) } \\
\text { фиолетовое (антоциановое) }\end{array}$ & $\begin{array}{l}+ \\
+ \\
+ \\
+ \\
+\end{array}$ & $\begin{array}{l}+ \\
+ \\
+ \\
+ \\
+\end{array}$ & $\begin{array}{l}+ \\
+ \\
+ \\
+ \\
+\end{array}$ & $\begin{array}{l}+ \\
- \\
+ \\
- \\
-\end{array}$ & $\begin{array}{l}+ \\
- \\
+ \\
- \\
-\end{array}$ & $\begin{array}{l}+ \\
+ \\
- \\
+ \\
-\end{array}$ & $\begin{array}{l}+ \\
+ \\
+ \\
+ \\
+\end{array}$ & $\begin{array}{l}+ \\
+ \\
+ \\
+ \\
+\end{array}$ & $\begin{array}{l}- \\
+ \\
+ \\
- \\
+\end{array}$ \\
\hline $\begin{array}{l}\text { Форма } \\
\text { округлое } \\
\text { удлинённое } \\
\text { Размер }\end{array}$ & $\begin{array}{l}+ \\
+\end{array}$ & $\begin{array}{l}+ \\
+\end{array}$ & $\begin{array}{l}+ \\
+\end{array}$ & $\begin{array}{l}+ \\
+\end{array}$ & $\begin{array}{l}+ \\
+\end{array}$ & $\begin{array}{l}+ \\
+\end{array}$ & $\begin{array}{l}+ \\
+\end{array}$ & $\begin{array}{l}+ \\
+\end{array}$ & $\begin{array}{l}+ \\
+\end{array}$ \\
\hline $\begin{array}{l}\text { крупное } \\
\text { мелкое }\end{array}$ & $\begin{array}{l}+ \\
+\end{array}$ & $\begin{array}{l}+ \\
+\end{array}$ & $\begin{array}{l}+ \\
+\end{array}$ & $\begin{array}{l}+ \\
+\end{array}$ & $\begin{array}{l}+ \\
+\end{array}$ & $\begin{array}{l}+ \\
+\end{array}$ & $\begin{array}{l}+ \\
+\end{array}$ & $\begin{array}{l}+ \\
+\end{array}$ & $\begin{array}{l}+ \\
+\end{array}$ \\
\hline
\end{tabular}

Рис. 5. Фрагмент таблицы вариантов признаков для разных видов семейства знаковых

Таблицы были построены не менее чем для десятка семейств культурных растений, таких непохожих, как пасленовые (картофель, помидоры, перец...), бобовые (горох фасоль, чина...), крестоцветные (капуста, редис...) и другие. Все таблицы показали наличие параллельных рядов ${ }^{2}$ признаков. Стало ясно, что сходные признаки, а иногда и ряды из них, свойственны не только разным особям одного вида, но и осо-

${ }^{2}$ Сами ряды впервые обнаружены Э. Бауром, изучавшим аборигенные сорта германских хлебов. бям внутри и родов, и семейств. Эти-то сходные ряды признаков Н.И. Вавилов и назвал гомологическими по аналогии с термином структурной химии. Гомологические - в соответствии с представлениями химии, то есть сходно построенные, - а не гомологичные в смысле заменяющие друг друга при скрещивании. Придя к этому выводу 12 мая 1920 г., Н.И. Вавилов окончательно убедился, что мысль о параллельной изменчивости как всеобщем биологическом законе, возникшая у него при изучении гербариев Линнея в Лондоне и коллекций растений Московского сель- 
скохозяйственного института, справедлива. Тогда свой доклад, готовящийся к III съезду селекционеров и семеноводов «Из генетики злаков (к вопросу о факторах формообразования)», он заменил докладом о законе гомологических рядов в наследственной изменчивости [8].

«Вместо того, чтобы изучать каждое растение в отдельности, - писал Н.И. Вавилов в статье по этому докладу, - можно изучить общую систему и в нее вводить только индивидуальные для линнеонов (то есть линнеевских видов. - M.P.) и родов признаки» [4, с. 21]. «Новые формы должны заполнить пустующие места в системе» $[4$, с. 51]. Оказалось, что общие варианты признаков обнаруживаются почти у всех единиц системы. Почти все пустые клетки таблиц для различных культур, а в первую очередь культур злаковых, Н.И. Вавилов со временем заполнил находками, сделанными в экспедициях. Остальные были получены позже методом химического мутагенеза, открытого (одновременно с английским генетиком Ш. Ауэрбах) и разработанного генетиком школы Н.К. Кольцова И.А. Рапопортом.

Открытый Вавиловым закон показывает, что: 1) наследственная изменчивость не безгранична, как полагали раньше; 2) она осуществляется закономерно, так что закон обладает предсказательной силой [17]. Это еще не классификация всех генов, но путь к ее созданию. В частности, он указывает на сходство поведения у генов разных уровней организованности.

\section{Закон Н.И. Вавилова и разные уровни строения генома}

Назвав свой закон по аналогии с гомологическими рядами в химии, Н.И. Вавилов отнес свою классификацию генов не к генам-атомам, а к генам-молекулам. «Ряды форм в пределах видов у растений и животных напоминают ряды углеводородов в органической химии, откуда... перенесено в биологию и само название гомологические ряды» [4, с. 159]. И уже в первой редакции Закона он подчеркнул, что рассматривает не только признаки, определяющиеся одним геном: «отдельные признаки могут обуславливаться несколькими наследственными факторами-генами, то есть могут иметь сложные наследственные формулы» [4, с. 11].

Понимая, что наследственная информация должна быть построена не менее сложно, чем вещество, химик сразу скажет, что ее система должна состоять из разных уровней организации. И потому не следует пренебрегать открытиями, сделанными на уровне «молекул» или на уровне, охватывающем широкий спектр организованности.

Обратим внимание: в каждом следующем издании «Закона гомологических рядов» Н.И. Вавилов, разъясняя свой закон, вносил все новые подробности из новейших открытий генетики, а формулировку закона оставлял слово в слово прежней:

«1. Виды и роды, генетически близкие, характеризуются сходными рядами наследственной изменчивости с такой правильностью, что, зная ряд форм в пределах одного вида, можно предвидеть нахождение параллельных форм у других видов и родов. Чем ближе генетически расположены в общей системе роды и линнеоны (то есть линнеевские видыл. - M.P.), тем полнее сходство в рядах их изменчивости.
2. Целые семейства растений в целом характеризуются определенным циклом изменчивости, проходящей через все роды и виды, образующие семейство».

См. эти же формулировки в [4, с. $17-18,82]$. В издании 1922 г. [4, с. 51-52] формулировка отличается, но не следует забывать, что это перевод 1987 г. Сам же Н.И. Вавилов считал издание 1935 г. расширенным и дополненным переводом издания 1922 г. [4, с. 56, сноска]. За этим сохранением формулировок стоит понимание и предвидение Н.И. Вавиловым сложности построения генетического аппарата, конкретных особенностей которого он, естественно, предвидеть не мог.

На том же съезде Е.И. Барулина сделала доклад о сорной вике, засоряющей посевы чечевицы. Она утверждала, что по размеру, форме и цвету семян сорная вика неотличима от чечевицы, и объяснила это явление мимикрией. Доложенный Н.И. Вавиловым закон объяснял, что за многие годы посевов чечевицы в сорной вике под влиянием отбора сохранились особи, содержащие гены семян, по размерам, форме и цвету гомологичные семенам культурной чечевицы. Остальное удалялось при сортировке семян и не высевалось с чечевицей на следующий год. В последующих изданиях «Закона...» Н.И. Вавилов уже отмечал, что некоторые случаи мимикрии связаны с проявлением закона гомологических рядов, но не все, а некоторые - те, когда похожими делаются особи сравнительно близких видов. Относил он к проявлениям закона гомологических рядов и некоторые случаи конвергенции, в основе возникновения которых действует тот же механизм, что у мимикрии [4, с. 50 и 94$]$.

Последующие работы о законе Н.И. Вавилова часто содержали в себе его подтверждения на примерах организмов из самых разных таксономических групп (окраска у собак [10] или птиц [12]); позже рассматривались даже микроорганизмы [13].

Саратовский генетик С.С. Хохлов отметил, что при изучении любого биологического явления на разных видах оказывается, что оно подчиняется закону Н.И. Вавилова [20]. Сам он изучал апомиксис, то есть бесполое размножение семенами у растений. И ему удалось показать, что и это сложное явление, требующее для своего возникновения явно более одной мутации, тоже подчиняется закону гомологических рядов в наследственной изменчивости.

После засилья лысенковщины генетика в нашей стране была реабилитирована лишь в 1964 г., а значит, уже после открытия двойной спирали и прочтения генетического кода. Слова «прочтение генетического кода» означают, что установлено, какие по структуре компоненты хромосом (нуклеотиды) ответственны за включение в белковую цепь той или иной аминокислоты. В первой же изданной после 1964 г. книге, посвященной Н.И. Вавилову, генетик М.Е. Лобашов писал: «Теперь мы можем распространить закон гомологии на молекулярный уровень строения генов» [15]. С конца 1970-х гг. появились быстрые методы определения порядка нуклеотидов в хромосоме, точнее, входящей в ее состав цепочке ДНК. Стало возможно прочтение структуры генов самого элементарного уровня «один ген - один фермент» (как бы гены-атомы) и составление генетиче- 
ских карт для интересующих исследователя видов. Обобщая работы на эту тему, И.А. Захаров писал: «Родственные виды, роды, семейства и т. д. обладают гомологичными генами и порядками генов в хромосомах, сходство которых тем полнее, чем эволюционно ближе сравниваемые таксоны. Гомология генов у родственных видов проявляется в сходстве рядов их наследственной изменчивости» [9]. В качестве примера приведена схема генетических карт человека, коровы, кошки и мыши, из которой видно, что у этих организмов, принадлежащих к разным отрядам млекопитающих, гомологичными являются не только многие «гены-атомы», но и порядок их расположения в хромосомах

Современная Вавилову генетика занималась в основном расположением генов в геноме (работы школ Моргана, Кольцова, Меллера и др.), что соответствует второму этапу развития атомистической методологии в генетике. А сам Н.И. Вавилов, изучавший и физиологию, и морфологию, и биохимию и географию культурных растений, но пользовавшийся в основном гибридологическим анализом, оказался несколько в стороне от общего движения. Не поэтому ли закон, открытый при изучении признаков действия дискретных наследственных задатков (генов) на разных уровнях организации, нередко игнорировался при исследовании каждого уровня отдельно. Так С.С. Четвериков в знаменитой статье 1926 г. [21] разъясняет, что мелкие мутации (геновариации), встречающиеся у наиболее изученного объекта генетиков, дрозофилы, являются не результатом воздействия человека, а свойственны природе вида. Среди них преобладают вредные для особи, но встречаются и полезные, и биологически безразличные. «При этом особенно интересно и важно отметить, что некоторые из этих биологически безразличных геновариаций, случайно возникающих среди нормального населения какого-либо вида, иногда соответствуют нормальным признакам соседних видов или даже родов и семейств [21, с. 177]. Неужели автор не заметил здесь проявления закона гомологических рядов? Ссылки на работы Н.И. Вавилова в статье отсутствуют.

И в наши дни разные исследователи объясняют проявления закона гомологических рядов через явления, связанные с теми уровнями организации генома, исследованием которых занимаются. И готовы спорить между собой, хотя рассматривают разные стороны одной медали. Закон справедлив и для современных генов молекулярной генетики, «генов-атомов» - «один ген - один фермент», над чем работает, например, И.А. Захаров [9], и для «генов-признаков» Менделя, о чем писал, скажем, Б.М. Медников [18]. И.А. Захаров, как сказано выше, подсчитывает на генетических картах гомологичные гены и отмечает гомологию генов в пределах даже крупных таксонов. Медников рассматривал цепи реакций, в результате которых возникают признаки. Достаточно прервать цепь в любой точке - и признак исчезает. Например, появляется альбинизм - отсутствие окраски.

На основе закона гомологических рядов в наследственной изменчивости Н.И. Вавилов разработал представление о политипической природе вида [4, c. $160-180]$.

\section{Другие открытия Н.И. Вавилова основанные на атомистической методологии}

Следующее фундаментальное открытие ученого, как и закон гомологических рядов, опирается на дискретность наследственных признаков. «Генетику так же, как и химику, приходится одновременно изучать и распределение элементов на Земле, - геохимию в широком смысле слова», - писал Н.И. Вавилов в одной из своих научно-популярных статей [6]. Выявились обширные области, где совпадает разнообразие признаков самых разных культур и присутствуют следы поселений древних земледельцев. Ученый назвал эти 7 областей центрами происхождения культурных растений, а внутри них выделил отдельные очаги [2]. После Н.И. Вавилова открыт лишь один центр происхождения культурных растений - на севере тропической Африки [14]. Однако идеи Н.И. Вавилова развивались, и выделен ряд вторичных центров, появилось понятие «области влияния» тех или иных центров; выделено вне Вавиловских центров 5 очагов происхождения декоративных растений [14, 16]. Строя карты, различные авторы часть Вавиловских очагов выделяют в отдельные центры, и таким образом насчитывают до 12 центров [16]. Если продолжать Вавиловскую параллель с геохимией в узком смысле слова, открытые им центры следует считать рудными полями и месторождениями материала для селекции.

Таким образом, Н.И. Вавилов изучил распределение атомов наследственности (генов) в пространстве, использовав методологический прием В.И. Вернадского, примененный к атомам химических элементов. Что касается распределения и развития генов во времени, то этот методологический подход впервые использовал С.С. Четвериков [21], чем фактически основал эволюционную генетику и существенно обогатил методологию атомистики.

В отличие от химии, в генетике существует понятие доминантности и рецессивности. В гетерозиготном, то есть содержащем две разных аллели по какому-то признаку организме, может проявиться лишь один из признаков, именуемый доминантным. Изучая ряды признаков у культурных растений разных видов, Н.И. Вавилов установил, что у каждой пары в ряду есть свои доминантный и рецессивный признаки. При этом признаки в ряду выстраиваются по доминантности. Сравнивая распределение генов по географическим ареалам, Н.И. Вавилов заметил, что в центре происхождения доминантные гены находятся в самой высокой концентрации. Особи выглядят однородными, а гибридологический анализ показывает самое высокое разнообразие форм. Чем дальше от центра происхождения, тем больше утеряно генов, в том числе доминантных, и, несмотря на бедность генотипа, которая проявляется благодаря скрещиваниям, внешне популяции выглядят более разнообразными, чем в центрах [3]. В областях распространения видов, отделенных от центров географическими барьерами, наблюдается «крайний рецессив» [3; 5, с. 71, 85]. Эти представления входят в учение о центрах происхождения и разнообразия культурных растений, которое, как и закон гомологических рядов в наследственной изменчивости, опирается на атомистическую методологию.

Трудно сказать, какое из двух фундаментальных открытий Н.И. Вавилова значительнее. 


\section{Литература}

1. Бокий Г.Б. Введение в кристаллохимию. М. : Изд-во МГУ, 1954. - 490 с.

2. Вавилов Н.И. Ботанико-географические основы селекции // Происхождение и география культурных растений. - Л. : Наука, 1987. C. 289-333.

3. Вавилов Н.И. Географические закономерности в распределении генов культурных растений // Происхождение и география культурных растений. - Л. : Наука, 1987. - С. 127-134.

4. Вавилов Н.И. Закон гомологических рядов в наследственной изменчивости. Избранные тр. по генетике. - Л. : Наука, 1987. - 260 с.

5. Вавилов Н.И. Из эпистолярного наследия 1929-1940 гг. - М. : Наука, 1987. - 493 с.

6. Вавилов Н.И. Происхождение культурных растений // Вавилов Н.И. Жизнь коротка, надо спешить. - М. : Советская Россия, 1990. С. 305-313.

7. Делоне Б.Н. и др. Математические основы структурного анализа кристаллов. - Л.; М. Госгеолтехиздат, 1934. - 378 с.

8. Есаков В.Д. Николай Иванович Вавилов. Страницы биографии. - М. : Наука, 2008. C. 104-111.

9. Захаров И.А. Генетическая гомология от Вавилова до эпохи генной инженерии // Природа. - 1987. - № 10. - С. 59-63.

10. Ильин Н.А. Генетика и разведение собак. - М.; Л., 1932.

11. Кедров Б.М. Атомистика // БСЭ. 3-е изд. T. II. - М. : Изд-во Советская энциклопедия, 1970. - C. 395-397.

12. Котс А.Ф. О гомологических рядах в окраске оперения Tetraonidae и Phaseonidae // Памяти академика Михаила Александровича Мензбира. - М.; Л. : Изд-во АН СССР, 1937. C. 211-234.
13. Кузнецьов В.Д. Параллелизм в наследственной изменчивости и популяционная концепция вида у представителей прокариот // Журн. общей биологии. - 1987. - Т. 48. - С. 466-476.

14. Купиов А.И., Раменская М.Е. Географические концепции Н.И. Вавилова и современность // Вавиловское наследие в современной биологии. - М. : Наука, 1990. - С. 147-154.

15. Лобашев M.E. Настоящее и будущее научного наследия Н.И. Вавилова // Н.И. Вавилов и сельскохозяйственная наука. - М. : Колос, 1969. - С. 392-393.

16. Лоскутов И.Г. История мировой коллекции генетических ресурсов растений в России. - СПб. : ГНЦ РФ ВИР, 2009. - 274 с.

17. Любищев A.A. Закон гомологических рядов Н.И. Вавилова и его значение в биологии // А.А. Любищев. Проблемы формы, систематики и эволюции организмов. - М. : Наука, 1982. - C. 247-253.

18. Медников Б.М. Закон гомологических рядов в наши дни // Наука и жизнь. - 1979. № 2. - С. 33 .

19. Урманцеев Ю.А. Начала общей теории систем // Системный анализ и научное знание. М. : Наука, 1978. - С. 7-41.

20. Хохлов С.С. Полвека закона гомологических рядов Н.И. Вавилова // Природа. - 1971. № 2. - С. 58-61.

21. Четвериков С.С. О некоторых моментах эволюционного процесса с точки зрения современной генетики // С.С. Четвериков. Проблемы общей биологии и генетики // Новосибирск : Наука, 1983. - С. 170-226.

22. Чудинов B.A. Атомистические концепции в современном естествознании: методологический анализ. - М. : Наука, 1986. - 78 с. 